\title{
Conditions for the lawful exercise of the right of self-defence in international law
}

\author{
V. Upeniece \\ Rīga Stradiņš University, Riga, Latvia
}

\begin{abstract}
The Charter of the United Nations was thought to establish a normative order, maintain international peace and security. According to the Article 51 of the Charter of the United Nations "Nothing in the present Charter shall impair the inherent right of individual or collective selfdefence if an armed attack occurs" [1]. However the Article 51 does not propose a legal definition of the conduct which is considered as an armed attack or the commencement of such an attack. It does not propose strict criterions for the use of force for self-defence. As a result different interpretations of this norm have been arising and continuing to change in response to new situations and threats.
\end{abstract}

Key words: self-defence; armed attack.

\section{Introduction}

In the General Treaty for Renunciation of War as an instrument of National Policy (Kellogg-Briand pact) the Contracting Parties condemned a recourse to a war for the solution of international controversies, renounced it as an instrument of the national policy in their relations with one another and agreed that the settlement or solution of all disputes or conflicts, which might arise among them, would never be solved except by pacific means [2]. According to the Preamble of the Treaty, if the Contracting Party seeks to promote its national interests by resort to a war, it will be denied the benefits furnished by this Treaty [3]. Thus, the commencement of hostilities against the Contracting Party which started the war was lawful and the war of self-defence was not prohibited by the Treaty [4].

\section{Discussion}

There are no debates about the statements that the right for self-defence, which is embodied in the Article 51 of the Charter of the United Nations, is the temporary right until the Security Council takes measures necessary to maintain international peace and security. The Article 51 of the Charter of the United Nations states that the force can be used in selfdefence only in relation to an armed attack [5]. The International Court of Justice in the case Nicaragua v. United States (1986) determined that an armed attack must raise to certain "scale and effect", therefore not all attacks can be qualified as armed attacks [6]. The international Court of Justice explained the meaning of the "armed attack" as "the most 
grave form of the use of force" [7] without going deeper into details and explanations of the meaning of the words "grave form of the use of force".

In the case Islamic Republic of Iran v. United States of America (2003) the International Court of Justice pointed out that the burden of proof of the fact of showing the existence of such attack rested on the State which justified its own use of force as self-defence [8]. It is clear that the use of force is lawful when the force is used as a response to the armed attack which has taken place. Obviously, the existence of an armed attack prevents any uncertainty. For this reason there is also a reasonable point of view that the lawful selfdefence is restricted to the response to the armed attack [9]. But if an actual attack has not yet occurred, it is necessary to understand whether the state can lawfully use the force for self-defence against a threat. Many scholars are against all forms of preventive actions. The others recognize the use of force for self-defence in response to imminent attack as lawful one.

The scholars often mention imminence as a criterion that justifies the use of force for self-defence. In the UN Secretary-General's High-Level Panel on Threats, Challenges and Changes it was mentioned, that the threatened state can take military action as long as the threatened attack is imminent [10]. The criterion of imminence correlates with the Caroline formula (1842), according to which the self-defence can only be exercised in the situations where the need to respond is instant, leaving no moment for deliberation [11]. There is no legal definition of imminence [12]. As examples of events that may indicate the presence of imminent threat of an attack mostly are mentioned: the enlargement of armed forces, procurement of weapons and belligerent declarations of intention to start a war, the other threatening activities and the other evidences that prove that an attack will take place in the nearest future [13].

Some scholars argue that imminence means the clear and present danger of an attack of an adversary, which is highly likely to occur. The others claim that the reference to the imminence of an attack is more the attempt to predict the future than constitution of the certain fact, because in different situations there may be a certain degree of uncertainty about the perfection of received information about the adversary's plans, intentions, and motivations [14]. According to Dinstein the armed attack of the adversary must be evident to the victim state, namely, the victim state can lawfully intercept the armed attack when it is in process of being started [15].

The criterion of imminence was also discussed in the Security Council after the Israeli attack on the Iraqi Osiraq nuclear reactor in 1981. Israel declared that "in the light of Iraqi declarations and deeds, and Iraq's refusal even to sign an armistice agreement with Israel, Israel had full legal justification to exercise its inherent right of self-defence to abort the Iraqi nuclear threat to Israel" [16]. The United Kingdom and Sierra Leone used the Caroline formula to explain the illegality of Israeli actions. The representative of Sierra Leone mentioned that "it has long been accepted that, for it to be invoked or justified, the necessity for action must be instant, overwhelming and leaving no choice of means and no moment for deliberation." The above-mentioned countries condemned the Israeli attack generally because the Israeli action was based on the long preparations and planning. Almost all the other states also condemned Israeli action generally because the threat was not imminent [17].

There is an opinion that the armed response is lawful only if it conforms to all conditions of necessity, proportionality and immediacy. The principle of necessity and immediacy, as expressed in the Carolina doctrine, is considered to be a part of the customary international law. According to the international customary law the self-defence is lawful if the response is necessary, proportional and immediate. The International Court of Justice made references to the principles of the international customary law in such cases as Nicaragua v. United States, Islamic Republic of Iran v. United States of America, 
Democratic Republic of the Congo v. Uganda and in the other cases. In Nicaragua case the Court recognized, that the Charter of the United Nations "does not contain any specific rule whereby self-defence would warrant only measures which are proportional to the armed attack and necessary to respond to it, a rule well established in customary international law" [18]. At the same time the Court evaluated the principle of immediacy, by stressing that "the reaction of the United States in the context of what it regarded as self-defence was continued long after the period in which any presumed armed attack by Nicaragua could reasonably be contemplated" [19]. In Oil Platform case the Court referred to the principle of necessity and proportionality and pointed out that "the United States must also show that its actions were necessary and proportional to the armed attack made on it and that the platforms were a legitimate military target open to attack in the exercise of selfdefence" [20]. At the same time in the case of Armed activities in Congo the Court indicated that "since the preconditions for the exercise of self-defence do not exist in the circumstances of the present case, the Court has no need to enquire whether such an entitlement to self-defence was in fact exercised in circumstances of necessity and in a manner that was proportionate" [21]. However in these cases the Court did not examine the question of the use of force for self-defence in the situation of existence of the threat of the use of armed force from the part of adversary.

The principles of necessity and proportionality are recognized as requirements of outstanding legal and practical importance for the right of self-defence [22]. The necessity requires the verification that the conflict cannot be solved by peaceful measures. There is an opinion, that the situation of absolute certainty that no other measures could prevent enemy attack also justifies the necessity, for example, in the situations of the direct threat to the state survival when the other options, except the use of force, cannot change the situation in a positive way [23]. The condition of the necessity requires the presence of conclusions, which are based on the proved facts, that an armed attack is imminent and requires the response [24]. Thus the use of force for self-defence should be a response to the real threat to the survival of a state. At the same time this principle contains the valid obligation to verify whether there are no other peaceful settlements of the conflict [25].

The principle of proportionality means that the use of force must be limited to the neutralization or abolition of the attack against which a state is defending itself [26]. According to Cassese the principle of proportionality requires not only the insurance of the balance between the injury caused by the wrongdoing state and the countermeasures, or at least the insurance that the countermeasures do not seriously exceed the injury created by the wrongful act, but also follows the aim to force the offender to discontinue its wrongful conduct [27]. The principle of proportionality does not require that the weapons used for self-defence must be the same as those, which are used for the attack. That is why the general prohibition of the first use of nuclear weapons is not derived from the principle of proportionality [28]. At the same time the International Court of justice could not reach a definitive conclusion about the legality or illegality of the use of nuclear weapons by a state in an extreme circumstance of self-defence, where its very survival would be at stake [29]. Consequently, the interpretation of this principle as one of the previously mentioned principle of necessity depend on the circumstances of each certain case and that is why is flexible.

The other criterion which requires an examination is the principle of immediacy. This criterion is also like a controversial issue. There is a point of view that the action in selfdefence must immediately follow the start of an attack. As Dinstein explains the isolated armed attack may not be the reason for starting a war for self-defence. At the same time he agrees that the principle of immediacy cannot be explained directly, because of different bureaucratic procedures the state faces with the beginning of hostilities by the adversary the certain period of time passes after the state officials make a decision to act in response 
and give the instruction to the armed forces. Therefore if the interval between an armed attack and a war of self-defence is long, a war may still be lawful if the delay is objectively justified [30]. The other scholars link the criterion of immediacy with the criteria of necessity and also deny that the beginning of an armed attack must be sufficiently close to the action for self-defence. Again the interpretation of closeness in time between these two actions is dependent on the context of each situation.

And lastly, the main disputable and controversial question is when or in which point of time the actions for self-defence become lawful. As it was mentioned above there is an opinion that the anticipatory self-defence is admissible if it complies with the requirements, which are set by Webster in the Caroline Case, namely, if the necessity of self-defence is instant, overwhelming and leaving no choice of means, and no moment for deliberation [31]. Still there is no unified attitude among the states to problem of lawfulness of the use of force for self-defence in the situation when the missile is already launched in the direction of the victim state and in the situation when a radar guiding the missile is locked on readiness to fire in the direction of the victim state [32]. The opponents of the anticipatory self-defence argue that Caroline formula does not broaden the right of selfdefence incorporated in the Article 51 of the Charter of the United Nations, because the Article 51 replaces the customary right of self-defence and prevails over it as a lex specialis. The main limitation of the use of force for self-defence derives from the phrase "if an armed attack occurs" which should be read in connection with the main purpose of the Charter of the United Nations to limit the unilateral use of force in international relations. According to this point of view the use of force for self-defence is lawful only after the armed attack had already been launched [33].

The International Court of Justice did not examine the question if the meaning of the phrase "if an armed attack occurs" actuates the Article 51. The International Court of Justice cites the Article 51 in the case Nicaragua v. United States and specifies that "the inherent right (or "droit naturel") which any State possesses in the event of an armed attack covers both collective and individual self-defence" and that in the examined case "reliance is placed by the Parties only on the right of self-defence in the case of an armed attack which has already occurred, and the issue of the lawfulness of a response to the imminent threat of armed attack has not been raised" [34]. In case the Armed activities in the Congo the Court also concluded that the force had not been used against an anticipated attack [35].

Some scholars recognize the legality of the interceptive self-defence. According to Dinstein the interceptive self-defence is lawful under the Article 51 of the Charter of the United Nations because it takes place in the situation when an armed attack is currently in progress. In such a situation he recognizes an armed attack as imminent and practically unavoidable. At the same time Dinstein stresses that the use of force should not be based only on the assumptions, expectations or fear [36].

The other opinion was expressed by Israel before the Security Council anent its actions against the Iraqi Osiraq nuclear reactor and is based on the idea that it would be cruelly to allow the adversary to deliver the first and perhaps the fatal blow in a nuclear age and epoch of developed technologies of destruction, which make it possible to destroy a state with great speed from long distances. The different interpretation of the Article 51 of the Charter of the United Nations would force the victim state passively except its fate and protect the aggressor right to the first strike [37].

The state's position in the issue of Iraqi Osiraq nuclear reactors acknowledges that mostly all the states recognize that the use of force in the period before an armed attack had occurred is not admissible if the force is used against an attack which is not clearly imminent. Although according to Lubell the states are playing the game of probabilities and trying to settle on the notion of "certain enough" that an attack is imminent [38]. There is an opinion among another group of scholars, that the use of force for self-defence is not 
restricted by the criterion of imminence in the situation of conviction that the attack will take place the nearest future.

\section{Conclusions}

The ways and means to ensure peace are diverse. At the same time the right to act for self-defence is reserved in the international law. Different points of view concerning the problem of the use of force for self-defence in response to the future attack which is imminent indicates its controversial nature. However the rapid changes in the modern world pose new challenges which need appropriate solutions.

Adopted in 1945 with the purpose to maintain the international peace and security the Charter of the United Nations is still the main source of the rules for evaluating the legality of the use of armed forces. The Charter of the United Nations contains both the prohibition on the use of armed force and the reference to the collective security system which is created to guarantee obedience for such a prohibition and is the first exception from the prohibition of the use of force expressed in the Article 2 (4) of the Charter of the United Nations. The second exception is embodied in the Article 51 and provides the legal bases for the use of force for self-defence.

The world is still facing the situations where an established rule - the prohibition of the use of force, continues to be challenged. Obviously, the purpose of the Article 51 of the Charter of the United Nations is dual, because from one side it poses a restriction to uncontrollable unilateral use of force, and from the other side it provides the states with the instrument which the states would use for their survival.

There is no definition, which would be applicable to all situations, including the situation when there is a threat of the use of force. There are debates about the right of the state to use force for self-defence against a threat of the use of force for the purpose to avoid being physically destroyed. So the question of the moment in time which is considered to be the point of commencement of an armed attack is also open. The scholars generally speak about criterions and preconditions of the use of force with precaution and avoid from giving precise definitions. Such situation may be explained with the reasonable disinclination to open the door for uncontrollable and unilateral abuse of this right. And at the same time, the shortage of precise definition opens the door for existence of different positions and interpretations.

\section{References}

1. Charter of the United Nations, available at:

http://www.un.org/en/sections/un-charter/chaptervii/index.html

2. General Treaty for Renunciation of War as an Instrument of National Policy (Kellogg-Briand Pact), 1928, available at: http://www. yale.edu/lawweb/avalon/imt/kbpact.htm

3. See ibid.

4. Dinstein Y. War, Aggression and Self-Defence, Cambridge University Press, 2005, p. $83-84$

5. Charter of the United Nations, available at http://www.un.org/en/sections/un-charter/chapter-vii/

6. Schmitt M.N. Cyber operations and the jus ad bellum revisited. Villanova Law Review, 2011, 56, p. 569-606 
7. Nicaragua v. United States, judgement of International Court of Justice, 1986, para. 191, available at: http://www.icj-cij.org/docket/files/ $70 / 6503 \cdot p d f$

8. Case Concerning Oil Platforms, 2003, 42 ILM 1334, 1356 (2003) (Islamic Republic of Iran v. United States of America), Judgement of 6 November 2003, para. 64 and 72, available at: http://www.icj-cij.org/docket/files/ 90/9715.pdf

9. Simma B., The Carter of the United Nations, commentary, second edition, Volume I, 2002, New York: Oxford University Press, 805p.

10. Report of the Secretary-General's High-Level Panel on Threats, Challenges and Change. A More Secure World: Our Shared Responsibility, A/59/565/, 2 December 2004, p. 62

11. The United States Secretary of State Daniel Webster dated 24 Apr. 1841, in Caroline Case, 29 British and Foreign State Papers (1841) 1137-1138, available at: http: / / avalon.law.yale.edu/19th_century/br-1842d.asp

12. Lubell N., The Oxford Handbook of The use of force in international law, edited by M. Weller, Oxford University Press, 2015, p. 702

13. Anad R., Self-Defence in International Relations, Palgrave Macmillan UK, 2009, $5 \mathrm{p}$.

14. Muller K.P., Catillo J.J., Morgan F.E., Pegahi N., Rosen B., Striking first. Preemptive and Preventive Attack in the U.S. National Security Policy. RAND Corporation, 2006, XIV

15. Dinstein Y. War, Aggression and Self-Defence, Cambridge University Press, 2005, p. 187

16. United Nations Security Council document S/PV.2283 of 15 June 1981, para. 79, available at:

http://repository.un.org/bitstream/handle/11176/67170/S PV. 2288-EN.pdf? sequence $=17$ \&isAl lowed $=y$

17. United Nations Security Council document S/PV.2283 of 15 June 1981, available at: http://repository.un.org/bitstream/handle/11176/67170/S PV. 2288-EN.pdf? sequence $=17$ \&isAl lowed $=y$

18. Nicaragua v. United States, judgement of International Court of Justice, 1986, para. 176, available at: http: //www.icj-cij.org/docket/files/ $70 / 6503 . p d f$

19. Ibid, para. 237

20. Islamic Republic of Iran v. United States of America, judgement of International Court of Justice, 2003, para. 51, available at: http: / /www.icj-cij .org/ docket/files/90/9715.pdf

21. Democratic Republic of the Congo v. Uganda, judgement of International Court of Justice, 2005, para. 147, available at: http://www.icj-cij.org/docket/ files/116/10455.pdf

22. Simma B., The Carter of the United Nations a commentary, second edition, Volume I, 2002, New York: Oxford University Press, 805p.

23. Green J.A. The ratione temporis elements of self-defence, Journal on the Use of Force and International law, 2015, 2, No.1, p. 101

24. Shaw M.N., International law, Cambridge University Press, 2003, 1031p.

25. Dinstein Y., War, aggression and self-defence, Fourth edition, Cambridge University Press, 2005, 237p.

26. Gutman R., Rieff D., Dworkin A., Crimes of War: What the public should Know, W.W. Norton \& Company, 2007, 341p.

27. Cassese A., International Law, Oxford University Press, 2005, 306p. 
28. Simma B., The Carter of the United Nations a commentary, second edition, Volume I, 2002, New York: Oxford University Press, 805p.

29. Legality of the threat of use of nuclear weapons, Summaries of Judgments, Advisory Opinions and Orders of the International Court of Justice Not an official document, 1p., available at: http://www.icj-cij.org/docket/files/ 95/7497.pdf

30. Dinstein Y. War, Aggression and Self-Defence, fourth edition, Cambridge University press, $242-243 p$.

31. The United States Secretary of State Daniel Webster dated 24 Apr. 1841, in Caroline Case, 29 British and Foreign State Papers (1841) 1137-1138, available at: http://avalon.law.yale.edu/19th_century/br-1842d.asp

32. Gray C. International Law and the Use of Force, Oxford University press, New York, 2000, 96p.

33. Simma B. The Charter of the United Nations a commentary, second edition, Volume I, 2002, New York: Oxford University Press, pp. 803-806

34. Nicaragua v. United States, judgement of International Court of Justice, 1986, 103p., para. 193, 194, available at: http: //www.icj-cij.org/docket/ files/70/6503.pdf

35. Democratic Republic of the Congo v. Uganda, judgement of International Court of Justice, 2005, para. 143, available at: http://www.icj-ij.org/docket/ files/116/10455.pdf

36. Dinstein Y., War, Aggression and Self-Defence, fourth edition, Cambridge University press, 2005, p. 191

37. United Nations Security Council document S/PV.2283 of 15 June 1981, para. 81-85, available at: http://repository •un.org/bitstream/handle/ $11176 / 67170 /$ S_PV.2288-EN.pdf? sequence=17\&isAllowed=y

38. Lubell N. The Oxford Handbook of The use of force in international law, edited by M. Weller, Oxford University Press, 2015, p. 714 
